\begin{tabular}{c|cc|c}
\hline 108 & $\begin{array}{c}\text { ARTICLES } \\
\text { Géza JESZENSzKY }\end{array}$ & $\begin{array}{c}\text { The Idea of Central Europe } \\
\text { and the Antall Government }\end{array}$ & \\
\hline
\end{tabular}

\title{
The Idea of Central Europe and the Antall Government
}

\section{Géza JESZENSZKY}

\begin{abstract}
Hungarian historian and diplomat, former Foreign Minister of Hungary (1990-1994), former Hungary's Ambassador to the United States of America (1998-2002) and to the Kingdom of Norway and Republic of Iceland (2011-2014)
\end{abstract}

"Does Central Europe Exist?" asked Timothy Garton Ash in 1986. He explained that "in Prague and Budapest the idea of Central Europe continued to be cherished between consenting adults in private, but from the public sphere it vanished, [...] the post-Yalta order dictated a strict and single dichotomy. Western Europe implicitly accepted this dichotomy by subsuming under the label 'Eastern Europe' all those parts of historic Central, East Central, and Southeastern Europe which after 1945 came under Soviet domination. [...] In the last few years we have begun to talk again about Central Europe, and in the present tense. This new discussion originated not in Berlin or Vienna but in Prague and Budapest. The man who more than anyone else has given it currency in the West is a Czech, Milan Kundera. (See his now famous essay "The Tragedy of Central Europe" in The New York Review of Books, 26 April 1984.)"11

"According to Kundera, Central Europe belonged to the West all along, and it was only the political developments following the Second World War that shifted it towards the East. [...] Central Europe became a highly attractive intellectual topic, but it also became part of the political agenda." ${ }^{2}$ Of course the term and the idea went back at least to the early $20^{\text {th }}$ century ("Mitteleuropa"), but the Habsburg, after 1867 the Austro-Hungarian Monarchy, or the term "Danubian lands," "Danube Basin" (C.A. Macartney) also denoted the area between Germany and Russia. But what used to be a convenient name for mainly a common culture became a rallying concept in the late 1980s. The denial of being Eastern Europe was a hardly disguised protest against Soviet-imposed communism. "The breakthrough of 1989 was nothing short of a historical victory of capitalism over socialism and the beginning of the return of the countries of Central Europe to their natural path of development, from which they were shoved by Communism." ${ }^{3}$

\footnotetext{
1 ASH, Timothy Garton: Does Central Europe exist? in: The New York Review of Books, 33, 1986, 15, 45-52. 2 KOPEČEK, Michal: Politics, Antipolitics, and Czechs in Central Europe: The Idea of "Visegrád Cooperation" and Its Reflection in Czech Politics in the 1990s, in: Questionable Returns, BOVE, Andrew (ed.), Vienna IWM, Junior Visiting Fellows Conferences, Vol. 12, 2002, online: http://www.iwm.at/wp-content/uploads/jc-12-01.pdf. 3 Ibidem.
} 
The solidarity of Poles and Hungarians was very old, and the Hungarian revolution of 1956 reaffirmed it. That friendship is largely traditional and patriotic. The Czech, Slovak and Hungarian "dissidents", on the other hand, were mostly disillusioned Marxists; they came to endorse "bourgeois democracy" after the Prague Spring of 1968, which showed that "socialism with a human face" was an impossible illusion. But the political earthquake of 1989 united the different types of anti-communists, and the free elections held throughout in Central Europe in 1990 led to firmly anti-communist and pro-western new politicians to run the governments.

In Hungary "Central Europe" was one of the battle cries of the emerging open political opposition in the late 1980s. Many writings revoked the struggles for independence and freedom by the victims of great power aggression and domination, which were usually characterized by various forms of mutual solidarity and help. The memory of the anticommunist risings (1956, 1968 and the many in Poland) was a bond uniting the core countries of "the sick heart of Europe." ${ }^{4}$ Following the widely read "samizdat" publications and the activities of the Soros Foundation the Hungarian legal media, too, was inundated by writings on Central Europe. Essays by Elemér Hankiss, Csaba Gy. Kiss, János Gyurgyák, and foreign authors all discussed the meaning and future of Central Europe. The most typical example was a special issue of the periodical Századvég (End of the Century). ${ }^{5}$ The list of authors is telling: Péter Kende, Endre Bojtár, György Gyarmati, Géza Jeszenszky, László Tőkéczki, Attila Melegh, Bobbio Norberto, György Schöpflin, Zbigniew Brzezinski, Timothy Garton Ash, Czeclaw Milosz, Matei Calinescu, Václav Bělohradský, Hans-Peter Burmesister, Marjan Rozan, Antun Soljan, Milan Šimečka, Mihály Vajda, Jane Mellor, Milan Kundera, Joszif Brodszkij, Emil Cioran, András B. Vágvölgyi, Bohumil Doležal, Emil Niederhauser, István Eörsi, Pál Szalai, Iván Völgyes, Attila Ágh, László Bogár, Csaba Vass, László Varga, Vilmos Heiszler, Gyula Borbándi, Bálint Balla, Ferenc Fejtő, Béla Faragó, Domokos Kosáry, Csaba Gombár, Gáspár Miklós Tamás.

Following the semi-free elections in Poland (June, 1989), the "Pan-European Picnic" on the Austro-Hungarian border on 19 August, the escape of tens of thousands of East Germans through Hungary in September, and the successful conclusion of the round-table talks in Hungary on 18 September the communist dominoes fell in rapid succession. The optimistic spirit, the expression of the hope for a truly new Europe, born in that "brief, shining moment" was the Christmas appeal of the Hungarian Democratic Forum. It is worth quoting in full.

"Now, in our hands we have a great opportunity to put an end to the conflicts that traditionally turned the peoples of this region against each other. Today, in Eastern Europe all swear by freedom of conscience, civil liberties, democracy, a free economy, the observance of human rights and self-determination. The basis for the new legal order can only be the Charter of the United Nations, the Helsinki Final Act, and the International Law of Human Rights adopted in 1976, including the Universal Declaration of Human Rights and the various Covenants concerning civil, political, economic, social and cultural rights.

4 SETON-WATSON, Hugh: The "Sick Heart" of Modern Europe, Seattle \& London 1975.

5 Kell-e nekünk Közép-Európa?, GYURGYÁK, János (ed.), Budapest 1989. 


\begin{tabular}{c|cc|c}
\hline 110 & $\begin{array}{c}\text { ARTICLES } \\
\text { Géza JESZENSZKY }\end{array}$ & $\begin{array}{c}\text { The Idea of Central Europe } \\
\text { and the Antall Government }\end{array}$ & \\
\hline
\end{tabular}

It was for these rights that Hungary fought in 1956, and Czechoslovakia stood up in 1968. It is for these rights that Charta 77, the Polish Solidarity and the opposition movements in other East European countries have struggled. They all suffered persecution for this cause. The burial of the martyred Hungarian Prime Minister Imre Nagy in June, 1989, was an unforgettable moment of coming together. The ceremonies were attended by representatives of the democratic Roumanian emigration, and we could come to an agreement on the basic principles for our common future.

Free nations ought to develop free contacts with each other; borders should not obstruct the movement of people, information and ideas. Our new democracies should be determined not to let old conflicts spring up, so that attention could be focused on creating a better future. This sentiment was universally expressed at the meeting of Polish, East German, Czech, Slovak, Bulgarian and Hungarian democrats on December 15-16, 1989 in Budapest, convened by the Hungarian Democratic Forum. Today, when we are all united under the impact of recent events and in the spirit of the Declaration of December 16, we propose that all the democratic organizations in Central and Eastern Europe publicly commit themselves to the preservation of our unity and the realization of our democratic, pluralistic ideals.

One of the cardinal prerequisites of democracy is toleration for those whose political views, religion or language differs -- for the various minorities. The practical realization of that principle is recognition of these groups' organization and autonomy in order to facilitate their free development. It is our hope that in the future social integration in the new democracies will go side-by-side with respect for regional, national and ethnic distinctions, and that representative democracy will be based upon local self-government. We hope that in the not too distant future all the nations and countries of Europe will endorse these ideals, including the concept of European unity, and thus will create the foundations for a real European home. In past centuries, the peoples of East-Central Europe could never stand together on the same side. Today, history offers us a unique opportunity for such a unity."

The first free, multi-party elections in Central Europe were held in Hungary in March and April, 1990. It was won be the Hungarian Democratic Forum, narrowly defeating the Alliance of Free Democrats. It led to the formation of the coalition government led by the "national liberal" and Christian Democratic József Antall. That government was committed to the idea of Central European affinity and solidarity. Presenting his government's program to Parliament Antall stated: "The changes in Central and Eastern Europe have given us a great opportunity to end or at least to alleviate the conflicts that traditionally turned the peoples of this region against each other. Free nations ought to develop free contacts with each other; borders should not obstruct the free movement of persons, information and ideas. We are confident than none of our neighbours will feel the need to use the Hungarians as the image of the foe, in order to keep themselves together. European cooperation goes hand-in-hand with intensive regional cooperation, and it is that what we seek to achieve with all our neighbours. At the same time in a federalizing Europe regionalism is the best

6 Type-written copy in my possession. All quotations from Hungarian are my translations - GJ. 
guarantee for the preservation national characteristics and serving national interests, free of intolerant nationalism. [...] We have to start a new chapter in our history, the era of understanding and tolerance between us, Hungarians, who suffered so much, and our neighbours, who struggle with a similar legacy. [...] We all belong to Europe. Brotherly coexistence and cooperation is the command of history for all of us, and history has proven that we should not allow ourselves rancour against each other, as that could be utilized against as. ${ }^{17}$

There was a potential stumbling block, the issue of the millions of Hungarian, German, Albanian, Polish etc. national minorities. Their very existence used to be a source of tensions and conflicts. During communism they suffered under double oppression: while everyone felt the iron hand of dictatorship, the anti-minority policies and practices of the totalitarian State added to the plight of the national minorities. In the optimistic mood of 1990 Antall stated: "It is time that the national minorities truly formed the most important bridge of friendship between countries, but this can only be done by communities who have regained their rights and sense of dignity. In this honest endeavour of ours, we are counting on the support of the governments and public opinion of democratic states. ${ }^{18}$ That may sound illusory today, but in 1990 the political atmosphere was quite promising in that field, too. The Copenhagen Ministerial Conference of the CSCE on the human dimension, held in June 1990 stated that "respect for the rights of persons belonging to national minorities as part of universally recognized human rights is an essential factor for peace, justice, stability and democracy," and recommended a large number of measures for their protection, including "appropriate local or autonomous administrations corresponding to the specific historical and territorial circumstances." ${ }^{\prime 9}$

In Hungary the hope was strong that the governments of Europe and North America were united in their support for the rights of national minorities. Parliamentary opinion was in line with the position of István Bibó, the widely respected political scientist, a member of Imre Nagy's revolutionary government in 1956. In 1946, learning the terms of the peace Hungary was expected to sign in 1947 Bibó wrote: "Hungary will faithfully respect and carry out the peace treaty, once it is signed. It would be insincere to pretend that she has become an enthusiastic adherent of the grave dispositions of the treaty. But Hungary will not create an ideology or organize political campaigns for changing the borders, and will not pursue a policy which speculates in international crises or catastrophes, so that her territorial grievances could be remedied. Hungary will comply with the conditions created by the peace treaty without any reservations, except one: she cannot give up her political interest in the fate of the Hungarian minorities [living in the states surrounding Hungary]." 10 I often emphasized that it was mistaken to think that the legacy of Central European history was all conflict. The idea to stand up jointly to aggression, to defend one's territory and

7 ANTALL József: Modell és valóság, Vol. 2, Budapest 1994, 64. Cf. ANTALL József: Selected Speeches and Interviews (1989-1993), Budapest 2008, 131-132.

8 ANTALL, 1994, 65.

9 Document of the Conference on the Human Dimension of the CSCE, Copenhagen, 29 June 1990 [online], available at: http://www.ena.lu/europe/organisation-security-cooperation-europe/conference-human-dimensioncsce-copenhagen-1990.htm

10 BIBÓ, István: A magyar békeszerződés, in: Válogatott tanulmányok. Vol. 2, Budapest 1986, 294-295. 


\begin{tabular}{c|cc|c}
\hline 112 & $\begin{array}{c}\text { ARTICLES } \\
\text { Géza JESZENSZKY }\end{array}$ & $\begin{array}{c}\text { The Idea of Central Europe } \\
\text { and the Antall Government }\end{array}$ & \\
\hline
\end{tabular}

heritage against aggressors was very old in Central Europe. It is enough to refer to the common struggles against the Ottoman onslaught from the $14^{\text {th }}$ to the $18^{\text {th }}$ centuries, to the many non-Hungarian volunteers in the Hungarian War of Independence of 1848-49, to the various plans for a federation or confederation, and to the strong sympathy shown in all the Central European countries for the various efforts to change the inhuman and irrational dictatorship imposed and maintained by the Soviet Union since the Second World War. In times of crisis the peoples usually sympathized with each other.

It is not true that the Antall-government made its policy towards its neighbours dependent on the treatment of their Hungarian minority. Such "an informal Antall-doctrine" was never enunciated, nor did it exist in the minds. On the other hand it would have been impossible to speak of genuinely good neighbourly relations with countries who mistreated their Hungarians. We were also against accepting the principle of "reciprocity" between national minorities very different in size, traditions and aspirations. When Hungary passed its much acclaimed Law 77 of 1993, conferring cultural autonomy and other extensive rights upon its own few thousand strong German, Slovak, Croat, Romanian, Serb, Slovene and other national minorities, this was not done in the naïve hope that it would be automatically reciprocated or imitated by the neighbouring states, the law simply expressed a conviction that European norms and practises (like South Tyrol, the Åland Islands, the position of the Germans in Belgium or in Denmark) as well as the very survival of those minorities required that.

So in 1990 Hungary declared a policy of extending the hand of friendship to all the neighbours, the Soviet Union included. It was hoped that on the basis of the common suffering under the dictatorships, by accepting the Western system of values, and being aware of the obvious community of interests, a new solidarity would emerge in Central Europe, and following the example of post second world war Western Europe our nations would put aside all old quarrels, so as to concentrate on political, economic, environmental and cultural recovery and reconstruction. There were already some regional initiatives we could build upon: the Alps-Adriatic Working Community going back to the late 1970s, and the Danube-Adriatic Cooperation of Italy, Austria, Hungary and the Socialist Federal Republic of Yugoslavia called also Quadragonale set up in Budapest on 11 November 1989. (It became the Pentagonale in April 1990 with Czechoslovakia joining, and Hexagonale in July 1991 when Poland was added; today it is the Central European Initiative comprising 18 countries.)

Hungary's neighbourhood policy went beyond mere words; we acted along the lines expressed above. The Antall-government was sworn in on 23 May 1990. I, as its Foreign Minister paid my first visit to our traditional partner, Austria, on 26 May. I found a very experienced partner and a most reliable friend in Vice Chancellor and Foreign Minister Dr. Alois Mock, a dedicated follower of the Central European idea. Next day Prime Minister Antall met the Deputy Prime Ministers of the Pentagonale in the border town of Sopron, and on 31 July the leaders of the cooperation met in Venice. In July I went to Belgrade and opened a Hungarian Consulate-General in Zagreb. My official visit to Czechoslovakia took place at the end of August. It coincided with the Prague conference of the U.S.based Aspen Institute. There the subject of the discussions was how Central Europe could overcome the legacy of its nationalist past. On Hungary's neighbourhood policy I 
said: "There is a solution different than border rectification: making the frontiers open, transparent, to build economic ties, regional cooperation. This is not a utopia: it has been tried in Western Europe and it works! The common aim of the former communist countries is to join Europe - they will join a house where there are enlightened rules that have to be accepted by the newcomers. Those who want to join the club will sign up." 11 The same topic (Ethnicity and Nationalism) was the theme of the conference of Wilson Center alumni held at Cambridge in early September. My key-note speech was optimistic, along the lines I expressed in Prague.

On 16 September the parties of Central Europe having a Christian Democratic character held a conference in Bratislava. Representing the Hungarian Democratic Forum I pointed out how important it was to dispel the fear that freedom regained would set free animosities and confrontations. The declaration we adopted emphasized the need for the effective protection of the national and religious minorities and held out the example of South Tyrol as a model to be followed. Although I could observe increasingly nationalistic and intolerant attitudes among the Slovaks, it was nothing like the hostility of the post-Ceausescu leadership in Romania towards the Hungarian minority. That was a great disappointment for Hungarians, as when the Romanian dictator was overthrown at Christmas, 1989, a remarkable solidarity emerged between the two neighbouring peoples. On the first anniversary of the Pan-European Picnic the Hungarian Democratic Forum initiated "Europe Day"-s, people-to-people meetings at eight border-crossings, envisaging a Europe where borders will be permeable and invisible. I went to Ártánd, on the Hungarian-Romanian border. I recalled that "all Hungary was cheering and praying for Romania on Christmas Eve last year." Both Romanians and Hungarians present welcomed my words that we want to live in a Europe "where borders are 'spiritualized' and lose their importance, where joint efforts can be made to redeem the material, moral and environmental destruction of the communist-Stalinist dictatorships. Romanian-Hungarian tensions under non-democratic regimes always grew, while among democratic conditions they improve, cooperation starts and that can lead to friendship. Our aim is a Europe where iron curtains, closed roads, suspended railway lines, and customs officers body-searching people will be gone..."12 Sadly, all our efforts to improve our relations with Romania failed, both the Romanian government and the public continued to show hostility both towards the Hungarian minority in Transylvania and Hungary proper; that made it impossible for me to visit Romania before September 1993, when Romania tried to be admitted to the Council of Europe.

The most meaningful realization of the Central European idea was the close political association of Poland, Czechoslovakia and Hungary named after its birthplace, Visegrád. At the initiative of Prime Minister Antall a Declaration of Cooperation was signed by President Walesa of Poland, President Havel of Czechoslovakia and Prime Minister Antall of Hungary on 15 February 1991 at the ancient royal see of Visegrád in Hungary, where the Polish, the Bohemian (that is Czech) and the Hungarian kings met in 1335. The goal of the cooperative mechanism was to help and speed up the transition of those countries from the Soviet

11 JESZENSZKY, Géza: The Danger of National Conflicts in Post-Communist East-Central Europe, Intervention at the Aspen Conference, Prague, 29 August 1990.

12 Hungarian Ministry of Foreign Affairs, Press Release 18/1990. 


\begin{tabular}{c|cc|c}
\hline 114 & $\begin{array}{c}\text { ARTICLES } \\
\text { Géza JESZENSzKY }\end{array}$ & $\begin{array}{c}\text { The Idea of Central Europe } \\
\text { and the Antall Government }\end{array}$ & \\
\hline
\end{tabular}

orbit to the Euro-Atlantic structures, monitoring each other, learning from each other, and coordinating their foreign policy in all directions. The Visegrád spirit - cooperation rather than rivalry - deserves special recognition as an instrument that eliminated potential animosities. By establishing this triangular relationship we made sure conflicts became unthinkable between us. Visegrád was the alternative to earlier, bad arrangements for the region, such as direct foreign domination (the Russian Empire absorbing most of Poland in the $18^{\text {th }}$ century, the Habsburg Empire between 1526 and 1867, and, in a far more brutal version, Hitler's Third Reich and the Soviet bloc), the attempt at non-democratic integration (the Austro-Hungarian Monarchy, 1867-1918), or nations ganging up against another and seeking support from selfish great powers (the so-called Little Entente in 1921-1938 and the alliance of Austria, Hungary and Italy in the mid-1930s). The "Visegrád policy" was an ideal balance between two traditional, but futile foreign political orientations, an exclusively eastern (relying on Russia, later on the Soviet Union) and a one-sided and illusionary western one (expecting "the West" to protect or liberate Central Europe from Turkish, Russian or German aggression). Since 1991 the close cooperation of the core Central European countries has been a cornerstone for stability in the post-Cold War period. At the May 1992 Prague summit of our cooperation Antall's address was a very strong argument for extending and deepening the trilateral ties. The emphasis was not on history but on the present: common internal difficulties, common external dangers, common aims, and on the future. "It is our opinion that these organizations [the European Community and NATO] will more readily receive us together. Whoever sees advantage in following a separate path will sober up in a few months' time." ${ }^{\prime 13}$ The presidency of the European Community (headed by Dutch foreign minister Hans van den Broek) was present at the summit, mainly to support Havel and his party for the upcoming elections. Antall's hint aimed at Vaclav Klaus, the opponent of Havel, who did not hide his aversion to the Visegrád association. Although he won the elections, he did not give up Visegrád. He agreed to the dissolution of COMECON and the establishment of the Central European Free Trade Agreement in December 1992. That was a logical concomitant of Visegrád.

Of course Central Europe is larger than the three, today four "Visegrád" states. Based on culture, religion and the Latin alphabet it includes Austria, Slovenia, Croatia and the three Baltic republics. Historically and politically the Orthodox Christian countries of the Balkan, also Romania and Moldavia may also be included in the term. Ukraine is just making an attempt to make a break with Eastern Europe, to leave the Russian sphere of interest. That larger Central Europe is much closer in traditions and mentality to Western (and Northern) Europe than to Russia, to the real Eastern Europe, but it has many distinct features - not only being much poorer. The countries of this region share much history and are interdependent. On 27 July 1991 Prime Minister Antall pointed out in Dubrovnik at the Pentagonale summit: "The unity of this region implies that if factors of insecurity and instability appear in any country, they will affect the entire area. Looking at it from a distance, from other continents, even Europe is rather small, so East-Central Europe is tiny. Therefore, if there is a crisis, insecurity or domestic conflict, not to say a civil war in any country among the states of the Hexagonale, perhaps in one of our next-door neighbour, it will afflict us all.

13 ANTALL, 2008, 279. 
It endangers the economic position of us all as well as the confidence we enjoy, since we are regarded as one region, and our neighbours' problems and destabilising factors affect us all. That is the reason why it is so important that we should be able to co-operate and be able to provide assistance to one another. That gives real meaning to Hexagonale." ${ }^{14}$ On the other hand Antall always emphasized the interdependence of Western and Central Europe: "Central Europe has always been a critical area, one exposed to various dangers. Being under foreign domination or being neglected, its autonomy and independence is never a purely European issue; it is always an international, a world issue. As a result of its having shaken off the Warsaw Pact, the western part of Europe may not be fully aware that a feeling of community and solidarity remain vitally important even today as the foundation of our security. Let me stress in this context the need for the continued existence of NATO and the importance of the presence of the United States. Precautions should also be taken to prevent old reflexes, nationalistic reflexes, from getting the upper hand in our Europe, fomenting enmity between the smaller and the larger countries. They have created European culture and European civilisation jointly. Conflicting notions opposed to the European idea should not be allowed to wax stronger in the heart of society, or even on its fringes." ${ }^{15}$

The Visegrád Cooperation is the product and realization of the Central European idea. It had its ups and downs but on the whole it only grew in strength. Many neighbouring countries indicated their readiness to join. The founders appreciated that but did not want to dilute the association. Their preference was and is for V4 Plus, or an enhanced Visegrád. In the South Slovenia and Croatia, in the North-East the Baltic States, or even the Northern 5 are close partners in many fields, including security. Central Europe is not an alternative to the European Union (let alone to an Eurasian Union), but allied with Western Europe these two regions guarantee that prophesies about Europe's decline will prove fallacious.

\section{Abstract}

The anti-communist intellectuals of Hungary knew only too well how much the Sovietimposed system was inferior to the Western "free world." Inspired by M. Kundera's famous essay on "The Tragedy of Central Europe," but also by $19^{\text {th }}$ and $20^{\text {th }}$ century Hungarian authors, they used the opportunity in 1989 to switch to a multi-party democracy following the West-European model. They expressed their dedication to Central European common interests and solidarity in the 1989 Christmas Manifesto of the Hungarian Democratic Forum, the party which, led by József Antall, won the free elections in Spring, 1990. The program presented to the Hungarian Parliament was an unambiguous endorsement of western values and a determination to work most closely with the rest of Central Europe, while also supporting the rights of the close to three million Hungarians who were transferred in the 1920 Peace Treaty to the countries neighbouring Hungary. The most meaningful realization of the Central European idea was the close political association of Poland, Czechoslovakia and Hungary created in February 1991 and named after its birthplace, Visegrád. The

14 ANTALL, 1994, 332. Cf. ANTALL, 2008, 262.

15 ANTALL, 1994, 351. Cf. ANTALL, 2008, 301. 


\begin{tabular}{c|c|c|c}
\hline 116 & $\begin{array}{c}\text { ARTICLES } \\
\text { Géza JESZENSZKY }\end{array}$ & $\begin{array}{c}\text { The Idea of Central Europe } \\
\text { and the Antall Government }\end{array}$ & \\
\hline
\end{tabular}

common themes of the larger Central European area were enunciated by Prime Minister Antall at the Hexagonale summit held in July 1991 in Dubrovnik.

\section{Keywords}

Central Europe, Hungary, Antall József, Hungarian Democratic Forum (MDF), national minorities, Visegrád Cooperation.

\section{References}

ANTALL József: Modell és valóság. Vol. 2, Budapest 1994.

ANTALL József: Selected Speeches and Interviews (1989-1993), Budapest 2008.

ASH, Timothy Garton: Does Central Europe exist? in: The New York Review of Books, 33, 1986, 15, 45-52.

BIBÓ, István: Válogatott tanulmányok. Vol. 2, Budapest 1986.

Document of the Conference on the Human Dimension of the CSCE, Copenhagen, 29 June 1990 [online], available at: http://www.ena.lu/europe/organisation-securitycooperation-europe/conference-human-dimension-csce-copenhagen-1990.htm Hungarian Ministry of Foreign Affairs, Press Release 18/1990.

JESZENSZKY, Géza: The Danger of National Conflicts in Post-Communist East-Central Europe, Intervention at the Aspen Conference, Prague, 29 August 1990.

Kell-e nekünk Közép-Európa?, GYURGYÁK, János (ed.), Budapest 1989.

KOPEČEK, Michal: Politics, Antipolitics, and Czechs in Central Europe: The Idea of "Visegrád Cooperation" and Its Reflection in Czech Politics in the 1990s, in: Questionable Returns, BOVE, Andrew (ed.), Vienna IWM, Junior Visiting Fellows Conferences, Vol. 12, 2002, online: http://www.iwm.at/wp-content/uploads/jc-12-01.pdf.

SETON-WATSON, Hugh: The "Sick Heart" of Modern Europe, Seattle \& London 1975. 